\title{
УДК 678-632
}

\section{СИНТЕЗ, СВОЙСТВА И ПРИМЕНЕНИЕ ПРОДУКТОВ ПОЛИМЕРИЗАЦИИ КАРДАНОЛА (ОБЗОР)}

\author{
(C) В.В. Глухих ${ }^{1 *}$, А.Е. Шкуро \\ ${ }^{1}$ Уральский государственный лесотехнический университет, Сибирский \\ тракт, 37, Екатеринбург, 620100 (Россия), e-mail: zj@weburg.me, \\ gvictor@e1.ru \\ ${ }^{2} О А О$ «Уралхимпласт», Северное шоссе, 21, Нижний Тагил, Свердловская \\ область, 622012 (Россия), e-mail: o.shishlov@ucp.ru
}

В обзоре рассмотрены получение, свойства и применение продуктов полимеризации и сополимеризации карданола, который является природным фенолом, полученным из растительного сырья - жидкости скорлупы орехов кешью (Cashew Nut Shell Liquid). Описаны результаты исследований полимеризации карданола в присутствии инициаторов катионного и радикального типов, перекиси водорода в присутствии ферментов и комплексных соединений. Показано, что катализаторы катионного и радикального типов приводят к полимеризации карданола за счет раскрытия двойных связей его алкильного заместителя. При окислительной полимеризации карданола рост полимерной цепи происходит с участием двойных связей фенольного кольца.

Ключевые слова: обзор, карданол, полимеризация, сополимеризация, продукты, свойства, применение.

\section{Введение}

Фенолсодержащие полимеры и материалы на их основе обладают рядом ценных эксплуатационных свойств, например такими, как водостойкость и термостойкость. Наибольшее применение в промышленности нашли фенолформальдегидные олигомеры и полимеры. Однако токсичность формальдегида создает проблемы в их производстве и использовании, и поэтому необходимо разрабатывать альтернативные технологии производства фенолсодержащих полимеров без использования формальдегида, например, базирующиеся на реакциях полимеризации [1]. Кроме того, существует необходимость в развитии технологий получения полимерных материалов из возобновляемых ресурсов с целью устранения зависимости промышленности от истощения невозобновляемых ресурсов [2].

В опубликованных обзорах [3-5] отмечается, что одним из доступных в большом количестве растительных ресурсов получения фенольных мономеров для синтеза полимеризационных полимеров является жидкость скорлупы орехов кешью - Cashew Nut Shell Liquid (ЖСОК, или CNSL). Эта жидкость используется в качестве основного сырья для промышленного производства карданола, производного фенола, имеющего ненасыщенную углеводородную цепь (C15) в мета-положении с одной-тремя двойными связями.

В обзорах [3-5] описаны химический состав, свойства и применение ЖСОК и карданола, подробно

Глухих Виктор Владимирович - профессор кафедры технологии переработки пластических масс, тел.: (343) 262-97-46, e-mail: gvictor@e1.ru Шкуро Алексей Евгеньевич - аспирант кафедры технологии переработки пластических масс, e-mail: zj@weburg.me

Шишлов Олег Федорович - директор по науке и развитию, тел.: (3435) 34-65-92, e-mail: shishlov@ucp.ru освещены вопросы получения карданолсодержащих полимеров реакциями поликонденсации [5].

В данном обзоре рассматриваются методы полимеризации и сополимеризации ЖСОК и карданола, свойства и области практического применения полученных олигомеров и полимеров, способы и условия их отверждения.

\footnotetext{
* Автор, с которым следует вести переписку.
} 
Состав ЖСОК зависит от многих факторов: места и условий произрастания дерева кешью Anacardium occidentale $L$, технологии обработки орехов кешью, технологии и условий проведения технологических процессов получения ЖСОК из скорлупы орехов кешью и ее обработки.

Известно $[4,5]$, что натуральная ЖСОК (N-CNSL) содержит в своем составе группу химических соединений, основными из которых являются анакардиновая кислота (I), карданол (II), кардол (III) и 2-метилкардол (IV):

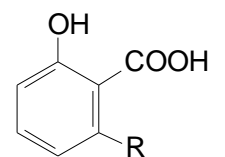

I

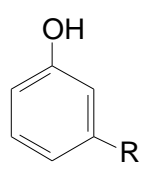

II<smiles>Oc1cc(O)cc(P)c1</smiles>

III<smiles>[R]c1cc(O)c(C)c(O)c1</smiles>

IV

где $\mathrm{R}$

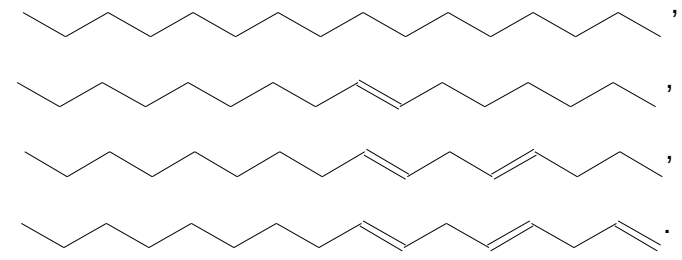

В продуктах тепловой обработки натуральной ЖСОК (D-CNSL и DD-CNSL) преобладает карданол, и они практически не содержат в своем составе анакардиновую кислоту.

Гомолимеры и сополимеры карданола получают, используя катализаторы различных типов: катионные, окислительно-восстановительные, ионно-координационные, радикальные.

\section{1. Катионная полимеризация карданола}

Катионную полимеризацию карданола изучал C.K.S. Pillai с коллегами [6-8]. В их публикациях отмечается, что имеется большое число патентов, в которых описывается катионная полимеризация карданола с использованием кислотных катализаторов, таких как серная кислота, фосфорная кислота, диэтилсульфат. Есть также примеры использования кислот Льюиса для полимеризации карданола, таких, например, как хлористый алюминий. Некоторые патенты описывают использование для полимеризации карданола металлических порошков или их оксидов.

В работе [6] описана катионная полимеризация карданола с эфиратом трехфтористого бора в качестве инициатора катонной полимеризации. С использованием гельпроникающей хроматографии (GPC) определены состав продуктов полимеризации карданола и их молекулярная масса. Химическое строение поликарданола подтверждено данными ИК- и ЯМР-спектроскопии.

Представлена типичная методика, в соответствии с которой 20 г карданола (0,67 моля) помещали в трехгорлую колбу с мешалкой, дефлегматором и вводом азота. Колбу устанавливали на масляную баню и нагревали до температуры $180{ }^{\circ} \mathrm{C}$. После этого к содержимому, тщательно перемешивая, добавляли эфират трехфтористого бора $(0,2$ г, $1 \%)$ под атмосферой азота. Синтез продолжался в течение 30 мин. После завершения реакции мономер и катализаторы отделялись от полимера промыванием метанолом.

Значения температуры (от 30 до $180{ }^{\circ} \mathrm{C}$ ), времени реакции (от 4 мин до 10 ч) и количества инициатора (от 0 до 3\%) варьировались с целью поиска оптимальных условий полимеризации карданола.

Установлено, что температура $140{ }^{\circ} \mathrm{C}$ при концентрации инициатора $1 \%$ является оптимальной для обеспечения максимального выхода полимера. Реакция проходит быстро, и время полимеризации в исследованном диапазоне практически не влияет на выход продуктов реакции. При этом не было получено 100\%-ной конверсии мономера. Даже после истечения 5 ч смесь продукта содержала 8-12\% мономера, что примерно соответствует содержанию насыщенных компонентов в карданоле. Следовательно, все ненасыщенные компоненты карданола прореагировали.

Была получена зависимость среднечисловой молекулярной массы от температуры реакции. Молекулярная масса увеличивалась от 730 атомных единиц при $30{ }^{\circ} \mathrm{C}$ до 3575 при $140{ }^{\circ} \mathrm{C}$, а затем уменьшалась до 1720 при $180{ }^{\circ} \mathrm{C}$. Полидисперсность полученного продукта увеличивалась от 1,2 при $30{ }^{\circ} \mathrm{C}$ до 3,4 при $140{ }^{\circ} \mathrm{C}$. 
Увеличение концентрации инициатора до $2 \%$ привело к незначительному уменьшению среднечисловой молекулярной массы полученного поликарданола и увеличению выхода димера (табл. 1).

Реакция полимеризации карданола с точки зрения кинетики является реакцией первого порядка относительно концентрации мономера. Были найдены константы скорости реакции: $6,67 \cdot 10^{3} \mathrm{c}^{-1}$ при $130{ }^{\circ} \mathrm{C}$ и $8,75 \cdot 10^{3} \mathrm{c}^{-1}$ при $140{ }^{\circ} \mathrm{C}$. По уравнению Аррениуса была вычислена энергия активации реакции 8,98 ккал/моль.

По мнению авторов [6], механизм полимеризации карданола в присутствии эфирата трехфтористого бора является цепным карбокатионным. На стадии инициирования происходит присоединение протона к атомам углерода с ненасыщенными связями в алкильном заместителе карданола. Обрыв цепи осуществляется путем передачи цепи на мономер. На примере карданола, содержащего одну ненасыщенную связь в боковой цепи, реакция его полимеризации может быть представлена следующей схемой:

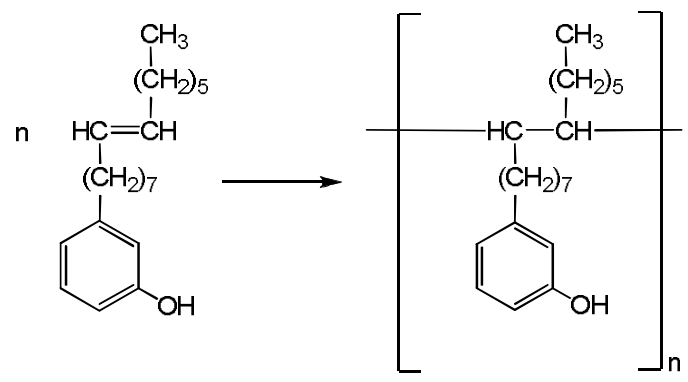

Эфират трехфтористого бора использовался также в работах C.K.S. Pillai и G. John [7, 8] для привитой катионной полимеризации карданола к целлюлозе с целью получения кислотостойкой бумаги.

В работе S. Manjula, V.G. Kumar, C.K.S. Pillai [9] исследована олигомеризация карданола с использованием кислотных катализаторов, каталитических систем диэтилсульфат - серная кислота (ДЭС - $\left.\mathrm{H}_{2} \mathrm{SO}_{4}\right)$ и диэтилсульфат - фосфорная кислота (ДЭС - $\mathrm{H}_{3} \mathrm{PO}_{4}$ ).

При использовании каталитической системы ДЭС - $\mathrm{H}_{2} \mathrm{SO}_{4}$ первоначально был подготовлен $25 \%$-ный раствор (по объему) серной кислоты в диэтилсульфате. По типичной методике 50 г (0,166 моля) карданола были смешаны с 3 мл катализатора (содержащего 0,014 моля серной кислоты и 0,017 моля диэтилсульфата) в трехгорлой колбе с мешалкой, обратным холодильником и вводом азота. Реакционная масса была нагрета до температуры $180{ }^{\circ} \mathrm{C}$ и перемешивалась в течение 30 мин. После реакции мономер и катализаторы были удалены промыванием метанолом. Эксперимент был повторен с изменением температуры, времени реакции и концентрации катализатора. Так как фосфорная кислота не растворяется в диэтилсулфате, то при использовании каталитической системы ДЭС - $\mathrm{H}_{3} \mathrm{PO}_{4}$ ее компоненты вводились в колбу раздельно. Оптимальные относительно выхода продукта условия реакции приведены в таблице 2.

Продукты олигомеризации были проанализированы методом гельпроникающей хроматографии. Было установлено, что полимеризация карданола в присутствии кислотных катализаторов дает смесь димера, тримера, тетрамера соответственно с молекулярными массами 600, 900 и 1200, а также ряд более высокомолекулярных олигомеров. Состав полученных продуктов (табл. 2), вычисленный с помощью данных GPC, приводится в таблице 3. Формирование малых количеств димера и тримера в реакции 2 без катализатора указывает на термическую полимеризацию карданола.

Сравнение ИК-спектров карданола и продуктов реакции его олигомеризации указывает на снижение количества двойных связей в С15 заместителе, что подтверждает протекание полимеризации карданола через раскрытие двойных связей в его боковой цепи.

Таблица 1. Влияние концентрации инициатора на полимеризацию карданола [4]

\begin{tabular}{c|c|c|c|c|c|c}
\hline \multirow{2}{*}{$\mathrm{BF}_{3} \cdot \mathrm{OEt}_{2}, \%$} & \multirow{2}{*}{ Мономер, \% } & \multirow{2}{*}{ Димер, \% } & \multicolumn{4}{|c}{ Полимер } \\
\cline { 3 - 6 } & & & $\%$ & $\mathrm{M}_{\mathrm{n}}$ & $\mathrm{M}_{\mathrm{w}}$ & $\mathrm{D}^{\mathrm{b}}$ \\
\hline 0,25 & 18 & 14 & 68 & 3000 & 6333 & 2,88 \\
0,5 & 15 & 13 & 72 & 3376 & 9542 & 2,83 \\
1,0 & 12,6 & 14 & 74,6 & 3763 & 11507 & 3,06 \\
2,0 & 14 & & 72 & 3184 & 10045 & 3,15 \\
$3,0^{c}$ & & & & & & \\
\hline
\end{tabular}

${ }^{\mathrm{a}}$ Полимеризация при $140{ }^{\circ} \mathrm{C}$ в течение 10 мин; ${ }^{\mathrm{b}} \mathrm{D}=\mathrm{M}_{\mathrm{w}} / \mathrm{M}_{\mathrm{n}}=$ полидисперсность; ${ }^{\mathrm{c}}$ мгновенная желатинизация. 
Таблица 2. Оптимальные условия олигомеризации карданола [9]

\begin{tabular}{c|c|c|c|c}
\hline $\begin{array}{c}\text { Номер } \\
\text { реакции }\end{array}$ & Катализатор, \% ${ }_{\text {об. }}$ & Температура, ${ }^{\circ} \mathrm{C}$ & $\begin{array}{c}\text { Продолжительность } \\
\text { реакции, мин }\end{array}$ & $\begin{array}{c}\text { Характеристическая } \\
\text { вязкость, дл/г }\end{array}$ \\
\hline 1 & 0 & 30 & 30 & 0,005 \\
2 & 0 & 180 & 30 & 0,009 \\
3 & 180 & 30 & 0,032 \\
4 & ДЭС $-\mathrm{H}_{2} \mathrm{SO}_{4}(6 \%)$ & 180 & 20 & 0,021 \\
\hline
\end{tabular}

Таблица 3. Процентный состав карданольного олигомера [9]

\begin{tabular}{c|c|c|c|c}
\hline Номер реакции & Мономер (M), \% & Димер (DM), \% & Тример (T), \% & Тетрамер (TM), \% \\
\hline 1 & 100,0 & - & - & - \\
2 & 94,13 & 2,68 & 3,19 & 59,39 \\
4 & 9,90 & 9,30 & 21,41 & 26,30 \\
\hline
\end{tabular}

На основании данных GPC, ИК- и ${ }^{1} \mathrm{H}$ ЯМР-спектроскопии авторы работы [9] склоняются к катионному механизму роста цепи путем присоединения протона ненасыщенному атому углерода в боковой цепи карданола в кислой среде по следующей схеме на примере структуры моноена (V):

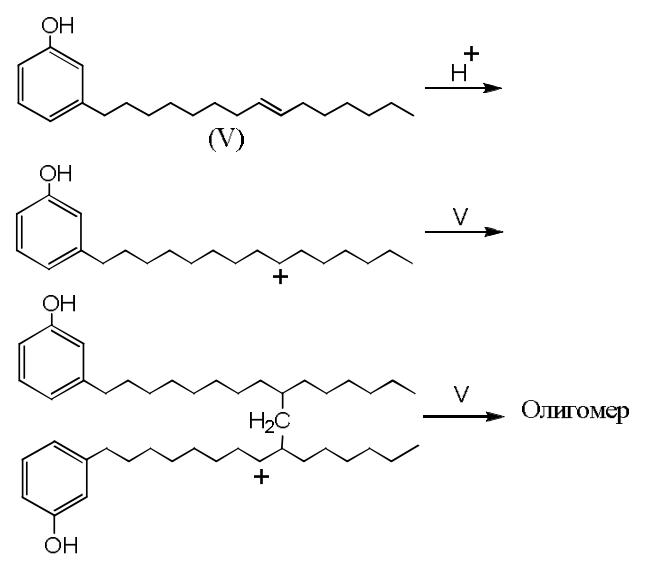

Выход димера, тримера и более высокомолекулярных олигомеров подчиняется одной закономерности, что предлагает цепной механизм олигомеризации. Поскольку димер - первый продукт реакции между двумя молекулами карданола (M), то на начальных стадиях реакции ожидалась его более высокая концентрация. Однако концентрация димера (D), тримера (T) и более высокомолекулярных олигомеров была одинаковой в любое время реакции. По мнению авторов [9], это, возможно, объясняет следующая кинетическая схема реакции моноена:

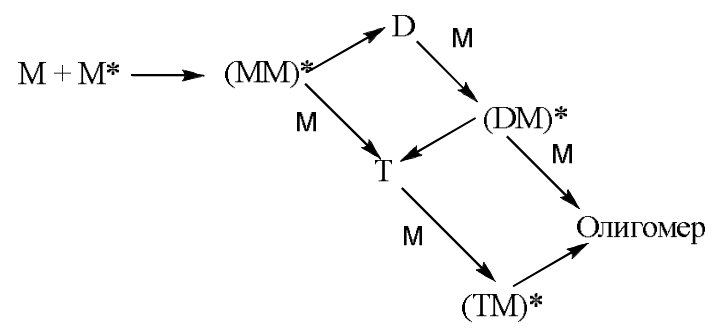

Изучение кинетики реакции олигомеризации карданола с каталитической системой DES $-\mathrm{H}_{2} \mathrm{SO}_{4}$ при $50{ }^{\circ} \mathrm{C}$ позволило авторам [9] высказать предположение о карбокатионном механизме реакции блочной полимеризации карданола с обрывом цепи через передачу цепи на мономер.

В патенте Республики Кореи [10] предлагается метод получения поликарданола блочной катионной полимеризацией карданола с сильными кислотами, кислотами Льюиса и их комплексными соединениями. Метод предусматривает полимеризацию карданола в присутствии 5\% мас. или менее количества катализатора катионной полимеризации. У полученного поликарданола среднечисловая молекулярная масса составляет 10000-100000 атомных единиц. Поликарданол может использоваться в качестве основы антикоррозионных покрытий. 


\section{2. Окислительная полимеризация карданола}

Ряд исследований окислительной полимеризации ЖСОК и карданола выполнил японский ученый S. Kobayashi с коллегами. В качестве окислителя использовался пероксид водорода в присутствии каталитических систем: ферментов и комплексных соединений металлов $[1,2]$.

Особенностью ферментативной полимеризации является возможность получения новых полимерных материалов, синтез которых обычными методами затруднен. Сообщается [1], что ферментативная полимеризация фенолов имеет следующие достоинства:

- окислительная полимеризация фенолов проходит при умеренных условиях реакции без использования токсических реактивов (экологически мягкий процесс);

- структурой и растворимостью полимера можно управлять, изменяя условия реакции;

- методики полимеризации и выделения полимера очень удобны.

Синтез поликарданола окислительной ферментативной полимеризацией карданола в растворе рассмотрен в работе [2]. В качестве катализатора использованы пероксидаза сои (ПС) и пероксидаза хрена (ПХ), а в качестве растворителей - ацетон, диоксан, изопропиловый спирт и его смесь с дистиллированной водой (табл. 4).

Реакция полимеризации проводилась следующим образом (реакция 4 в табл. 4). Смесь 0,60 г (2,0 ммоль) карданола и 20 мг ПС в 12,5 мл изопропилового спирта и 12,5 мл фосфатного буфера (рН 7) помещена в колбу объемом 50 мл. Перекись водорода (6\%-ный водный раствор, 1,5 мл, 2,0 ммоль) была прибавлена к смеси по каплям в течение 6 ч при комнатной температуре и осторожном перемешивании. После 24 ч реакционная смесь была сконцентрирована при пониженном давлении. К остатку прибавлен этилацетат (20 мл), и органический слой был отделен после удаления растворителя при пониженном давлении. Масляный остаток смешали с избытком холодного метанола. Не растворимая в метаноле часть была отделена центрифугированием и высушена под вакуумом. Выход поликарданола, который представлял собой вязкое, темно-желтое масло, составил 0,41 г (69\%). Полученный полимер растворим в хлороформе, диметилформамиде, этилацетате и не растворим в ацетоне и метаноле. Его молекулярные характеристики среднечисловая молекулярная масса $\left(\mathrm{M}_{\mathrm{n}}\right)$ и полидисперсность $\left(\mathrm{M}_{\mathrm{n}} / \mathrm{M}_{\mathrm{w}}\right)$ определены методом жидкостной хроматографии.

Результаты экспериментов показали (табл. 4), что пероксидаза хрена, в отличие от пероксидазы сои, не приводит к окислительной полимеризации карданола в среде ацетона и фосфатного буфера. Тип растворителя и содержание ПС в реакционной смеси влияют на выход нерастворимого полимера.

Таблица 4. Окислительная ферментативная полимеризация карданола ${ }^{a}$

\begin{tabular}{|c|c|c|c|c|c|c|c|}
\hline \multirow{2}{*}{$\begin{array}{c}\text { Номер } \\
\text { реакции }\end{array}$} & \multirow{2}{*}{$\begin{array}{c}\text { Количество } \\
\text { мономера, } \\
\text { ммоль }\end{array}$} & \multirow{2}{*}{$\begin{array}{c}\text { Растворитель } \\
\text { (объемное отноше- } \\
\text { ние) } \\
\end{array}$} & \multirow{2}{*}{$\begin{array}{l}\text { Катализа- } \\
\text { тор, мг }\end{array}$} & \multicolumn{3}{|c|}{ Растворимый продукт } & \multirow{2}{*}{$\begin{array}{c}\begin{array}{c}\text { Нерастворимый } \\
\text { продукт }\end{array} \\
\text { Выход, \% } \\
\end{array}$} \\
\hline & & & & Выход, \% & $M_{n}$ & $\mathrm{M}_{\mathrm{n}} / \mathrm{M}_{\mathrm{w}}$ & \\
\hline 1 & 5 & $\begin{array}{c}\text { Ацетон / Фосфатный } \\
\text { буфер (75:25) }\end{array}$ & ПС (20) & 21 & 4800 & 1,7 & 19 \\
\hline 2 & 5 & $\begin{array}{c}\text { Ацетон / Фосфатный } \\
\text { буфер }(75: 25)\end{array}$ & ПХ (20) & 0 & 0 & & 0 \\
\hline 3 & 5 & $\begin{array}{c}\text { 1,4-Диоксан / Фос- } \\
\text { фатный буфер ( } 85 \text { : } \\
15)\end{array}$ & ПС (20) & 0 & 0 & & 0 \\
\hline 4 & 2 & $\begin{array}{l}\text { Изопропанол / Фос- } \\
\text { фатный буфер (50 : } \\
50)\end{array}$ & ПС (10) & 69 & 6100 & 1,8 & 0 \\
\hline 5 & 2 & $\begin{array}{l}\text { Изопропанол / Фос- } \\
\text { фатный буфер (50 : } \\
50)\end{array}$ & ПС (50) & 0 & 0 & & 100 \\
\hline 6 & 2 & $\begin{array}{c}\text { Изопропанол / Фос- } \\
\text { фатный буфер (70 : } \\
\text { 30) }\end{array}$ & ПС (10) & 0 & 0 & & 35 \\
\hline 7 & 2 & $\begin{array}{c}\text { Изопропанол / вода } \\
(50: 50)\end{array}$ & ПС (10) & 38 & 10000 & 4,6 & 35 \\
\hline
\end{tabular}

${ }^{a}$ Полимеризация карданола (0,6 г) при катализе ферментами в органическом растворителе (25 мл) при обычной температуре в атмосфере воздуха. 
На основании данных ${ }^{1}$ Н ЯМР- и Фурье-ИК-спектроскопии авторы [2] считают, что во время реакции полимеризовалась только фенольная часть карданола, а его ненасыщенные группы в алкильном заместителе не прореагировали, и полученный поликарданол состоит из смеси полиалкилфенилена и полиалкилоксифенилена:
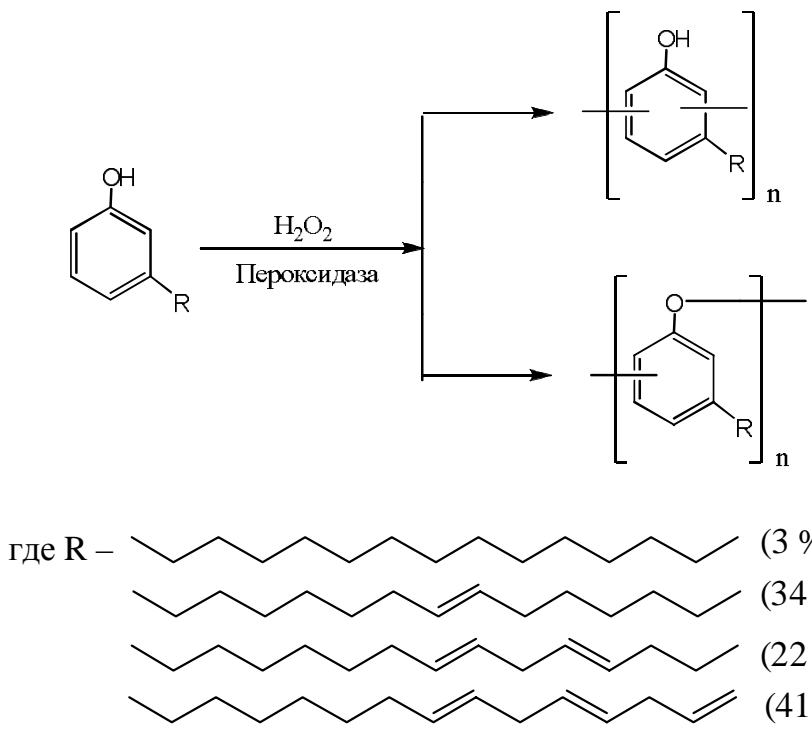

Полученный полимер был подвергнут отверждению с нафтенатом кобальта в качестве катализатора, что привело к образованию сшитой пленки с высоким блеском поверхности, пригодной для практического применения [2].

Исследована [11] ферментная полимеризация карданола и его гидрогенизированной формы (3-пентадецилфенол). Полимеризация катализировалась пероксидазой хрена в присутствии $\mathrm{H}_{2} \mathrm{O}_{2}$ в растворе смеси диоксан - вода в течение 24 ч при комнатной температуре. Показано, что выход полимера зависит от концентрации диоксана в смеси (72-85\%) и $\mathrm{pH}$. Гомополимеры фенолов растворимы в водном диоксане. Карданол и 3-пентадецилфенол сополимеризовали с фенолом, $n$-этилфенолом и $n$-фенилфенолом. Реакция проходит за 20-30 мин с выходом сополимера 90\%. Сополимеры не растворяются в обычных растворителях из-за сшивок, не имеют четкой морфологии и имеют пониженную термическую стабильность по сравнению с гомополимерами.

Осуществлена окислительная ферментативная полимеризация карданола в водно-органических смесях под действием грибковой пероксидазы [12]. При температурах реакции $10-15^{\circ} \mathrm{C}$ конечный продукт получен с высоким выходом. Установлено, что скорость подачи пероксида водорода влияет на начальную скорость реакции и конверсию карданола.

В работе [1] представлены результаты исследований окислительной блочной полимеризации ЖСОК с повышенным содержанием карданола (83-84\%) в присутствии перекиси водорода с использованием в качестве катализаторов Fe-Salen и комплексных соединений различных металлов ( $\mathrm{Fe}, \mathrm{Co}, \mathrm{Cu}$ и др.) c Salen, ацетилацетоновым и фталоцианиновым лигандами. Fe-Salen катализатор представляет собой Fe-N,N'этиленбис(салицилиденамин).

В работе использована следующая типичная методика полимеризации. Под воздухом и при комнатной температуре ЖСОК (6,0 г, 20 ммоль) и Fe-Salen (64 мг, 0,20 ммоль) были помещены в сухую стеклянную колбу. Туда же при перемешивании была добавлена перекись водорода (30\%-ный раствор, 2,3 мл, 20 ммоль). После 2 ч полимеризации небольшое количество реагирующей смеси было отобрано для определения степени конверсии карданола и молекулярной массы полимера методом жидкостной хроматографии.

Блочная окислительная полимеризация ЖСОК с использованием твердого катализатора Fe-Salen под воздухом при количестве катализатора от 0,5 до 1,5\% привела к получению растворимого полимерного продукта (поли-ЖСОК), выход которого находился в прямой зависимости от количества катализатора. Молекулярная масса полимера, полученного при использовании $0,5 \%$ катализатора, оказалась ниже, чем при 1,0 или $1,5 \%$. Выход и молекулярная масса полимера, полученного за 30 мин, были близки к массе и выходу полимера, синтезированного в течение 2 ч. Концентрация перекиси водорода влияла на полиме- 
ризацию незначительно. Выход поли-ЖСОК составлял от 38 до 80\%, среднечисловая молекулярная масса от 1400 до 3000 единиц, а степень полидисперсности $\left(M_{w} / M_{n}\right)$ - от 1,6 до 4,5.

Во время полимеризации ЖСОК в массе температура достигала $140{ }^{\circ} \mathrm{C}$ вследствие протекания экзотермической реакции. Добавление в реакционную массу пиридина, в отличие от полимеризации фенолов в растворе, катализируемой Fe-Salen, привело к уменьшению выхода полимера.

Исследование блочной окислительной полимеризации ЖСОК с комплексными соединениями различных металлов с Salen, ацетилацетоновым и фталоцианиновым лигандами показало, что комплексные соединения металлов с Salen лигандами являются оптимальным катализатором для окислительной полимеризации фенолов.

Анализ ${ }^{1} \mathrm{H}$ ЯМР-спектров полученного поли-ЖСОК показал, что ненасыщенные связи в алифатических заместителях практически не прореагировали во время окислительной полимеризации.

По результатам газовой хроматографии пики, относящиеся к II, стали меньшими, а пики III и IV почти исчезли, что предполагает более высокую реакционную способность кардола и метилкардола к окислительной полимеризации по сравнению с карданолом.

Отверждение поли-ЖСОК, полученного окислительной полимеризацией в растворе диоксана и в блоке, исследовано двумя методами: катализом с нафтенатом кобальта (3\% веса от массы полимера) и термообработкой (150 или $180{ }^{\circ} \mathrm{C}$ в течение 30 мин). Использовались поли-ЖСОК без очистки (содержание остаточных мономеров 23-41\%) и продукт его переосаждения из диоксана метанолом. Результаты исследований показали, что процессы отверждения, по данным ИК-спектроскопии, сопровождаются уменьшением концентрации двойных связей в алкильных заместителях. Скорость отверждения при использовании нафтената кобальта меньше по сравнению с термообработкой. По большинству показателей физико-механических свойств и химической стойкости пленки полученные термоотверждением поли-ЖСОК не уступают пленкам из промышленного образца полимера, полученного конденсацией ЖСОК с формальдегидом.

\section{3. Радикальная привитая полимеризация карданола}

Q. Chen, H. Xue, J. Lin [13] сообщают о проведении ими реакции прививки карданола к полипропилену в расплаве. Основной целью прививки являлось увеличение поверхностной активности полипропилена при изготовлении композиционного материала, полученного экструзией смеси полипропилена, карданола и бамбукового порошка.

В исследовании использовался порошок изотактического полипропилена (ПП) с показателем текучести расплава 2,1-6 г/10 мин. В качестве инициатора радикальной полимеризации применялась перекись дикумила (ДКП). Карданол был приобретен на местном рынке и использовался без дополнительной очистки.

Процедура получения привитого карданолом полипропилена заключалась в следующем: предварительно рассчитанные количества карданола, полипропилена и перекиси дикумила смешивались в коллоидной мельнице при 2600 об./мин и нормальных условиях. Затем полученная смесь экструдировалась в двухшнековом экструдере при $180{ }^{\circ} \mathrm{C}$ и 50 об./мин. Экструдат охладали в водяной бане и гранулировали, а затем растворяли в кипящем ксилоле и переосаждали в ацетоне с целью очистки. Готовый продукт был высушен под вакуумом при $80{ }^{\circ} \mathrm{C}$ в течение 12 ч.

Для доказательства прививки карданола к полипропилену использовали методы УФ- и Фурье-ИКспектроскопии.

На основании данных ИК-спектров полипропилена, экструдированного в присутствии 0,2\% ДКП без добавки карданола (dПП) и в присутствии карданола (ПП-g-карданол), авторы [13] предложили следующий механизм прививки карданола. По их мнению, первичные радикалы, образовавшиеся при термическом распаде ДКП, преимушественно реагируют с двойными связями в алкильном заместителе карданола и в результате разнообразных реакций образования активного центра и обрыва цепи приводят в основном к прививке молекул карданола к цепи полипропилена, например, по следующей схеме: 


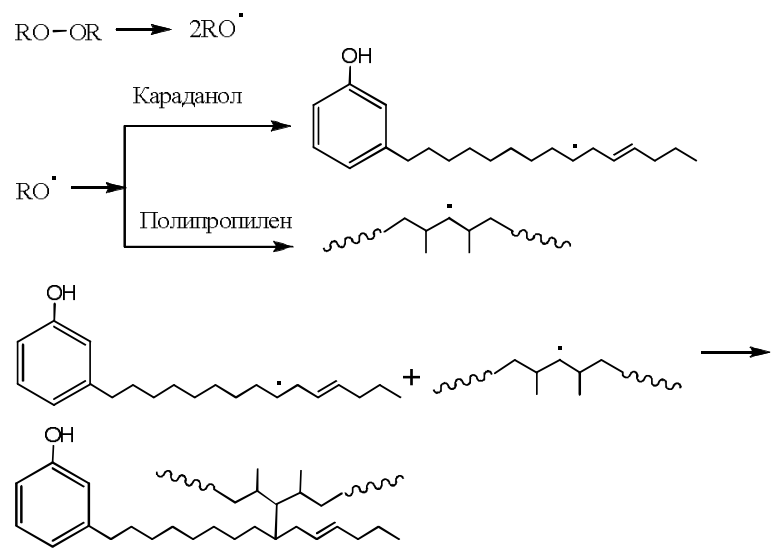

В ходе экспериментов не наблюдалось образование нерастворимых сетчатых полимеров карданола и полипропилена.

На основании полученных зависимостей степени прививки карданола к полипропилену и показателя текучести расплава полимера (ПТР) от содержания в рецептуре карданола и инициатора радикальной полимеризации был сделан вывод о том, что в присутствии карданола замедляется термическая деструкция молекул полипропилена.

Наибольшая эффективность прививки карданола к ПП (доля привитого карданола от содержания его в рецептуре) достигается при введение 3-4 г карданола на каждые 100 г полипропилена. Повышение концентрации дикумила в исходной смеси увеличивает объем привитого карданола в продукте.

Увеличение количества привитого карданола ведет к уменьшению ПТР ПП-g-карданола, а увеличение концентрации инициатора, напротив, к увеличению этого показателя.

Исследования краевого угла смачивания полипропилена на поверхности воды ПП-g-карданола показывают снижение его гидрофобных свойств относительно исходного ПП.

Свойства ПП-g-карданола, исходного ПП и полученных на их основе древесно-полимерных композитов с бамбуковым порошком (соответственно ПП/БП и ПП-g-карданол/БП) приведены в таблице 5.

Результаты экспериментов показали, что прививка карданола на $20 \%$ снижает модуль упругости Юнга и прочность при растяжении ПП-g-карданола относительно исходного полипропилена, однако почти в 20 раз увеличивает показатель удлинения при растяжении. Древесно-полимерный композит с ПП-gкарданолом при одинаковой прочности ДПК с ПП в 2 раза превосходит его по показателю удлинения при растяжении. Методом электронной сканирующей микроскопии показана более плотная и однородная упаковка наполнителя в ДПК при использовании ПП-g-карданола, что объясняется его лучшей адгезией к поверхности частиц бамбука.

Таблица 5. Прочностные свойства и кристалличность [13]

\begin{tabular}{c|c|c|c|c}
\hline Образец & $\begin{array}{c}\text { Модуль Юнга, } \\
\text { МПа }\end{array}$ & $\begin{array}{c}\text { Прочность } \\
\text { при растяжении, МПа }\end{array}$ & $\begin{array}{c}\text { Удлинение } \\
\text { при растяжении, \% }\end{array}$ & Кристалличность, \% \\
\hline ПП & $1005 \pm 24$ & $54,5 \pm 0,30$ & $41 \pm 2$ & 48,2 \\
ПП-g-карданол & $808 \pm 28$ & $45,1 \pm 0,98$ & $846 \pm 23$ & 47,2 \\
ПП/БП & $1498 \pm 55$ & $31,43 \pm 1,07$ & $16 \pm 1$ & 24,79 \\
ПП-g-карданол/БП & $1226 \pm 51$ & $31,49 \pm 1,49$ & $37 \pm 1$ & 24,49 \\
\hline
\end{tabular}

\section{Заключение}

Карданол как продукт растительного происхождения используется в качестве мономера для получения полимеризационных полимеров. Выполнен ряд исследований по изучению закономерностей полимеризации карданола в присутствии катализаторов различного механизма действия. Показано, что в зависимости от типа используемой каталитической системы реакция полимеризации карданола идет либо за счет раскрытия двойных связей алкильного заместителя, либо фенольного кольца. Продукты полимеризации карданола могут быть перспективными бесформальдегидными связующими при получении полимерных композитов, в частности, в производстве древесных композиционных материалов. 


\section{Список литературы}

1. Ikeda R., Tanaka H., Uyama H., Kobayashi S. Synthesis and curing behaviors of a crosslinkable polymer from cashew nut shell liquid // Polymer. 2002. Vol. 43, N12. Pp. 3475-3481.

2. Ikeda R., Tanaka H., Uyama H., Kobayashi S. Enzymatic-synthesis and curing of poly(cardanol) // Polymer J. 2000. Vol. 32, N7. Pp. 589-593.

3. Manjula S., Pillai C.K.S. Naturally Occurring Organic Bio-Monomers as Possible Future Sourses for Polymers // Polymer News. 1987. Vol. 12, N12. Pp. 359-367.

4. Talbiersky J., Polaczek J., Ramamoorty R., Shishlov O. Phenols from Cashew Nut Shell Oil as a Feedstock for Making Resins and Chemicals // OIL GAS Europeen Magazine. 2009. N1. Pp. 33-39.

5. Шишлов О.Ф., Глухих В.В. Синтез, свойства и применение продуктов поликонденсации карданола с формальдегидом (обзор) // Химия растительного сырья. 2011. №1. С. 5-16.

6. Antony R., Pillai C.K.S. GPC Studies on The Cationic Polymerization of Cardanol Initiated by Borontrifluoridediethyletherate // J. Appl. Polym. Sci. 1990. Vol. 41. N7-8. Pp. 1765-1775.

7. John G., Pillai C.K.S. Grafting of bio-monomers. 1. Cationic graft copolymerisation of cardanol using borontrifluoridediethyletherate onto cellulose // Polym. Bull. 1989. Vol. 22, N1. Pp. 89-94.

8. John G., Pillai C.K.S. Chemical modification of cellulose by cationic grafting of vinyl biomonomers: Structure and properties // 33rd IUPAC Int. Symp. Macromol., Montreal, July 8-13, 1990: Book Abstr. [Montreal]. 1990. P. 273.

9. Manjula S., Kumar V.G., Pillai C.K.S. Kinetics and Mechanism of Oligomerization of Cardanol Using Acid Catalysts // J. Appl. Polym. Sci. 1992. Vol. 45. N2. Pp. 309-315.

10. Patent 20030038937 (KR). Preparation method of cardanol polymer / Choi Jeong Su, Park Jae Yeon. 2003.

11. Alva K.Sh., Nayak P.L., Kumor J., Tripanthy S.K. Enzymatic polymerization of phenolic biomonomers derived from Cashew nut shell liquid // J. Macromol. Sci. A. 1997. Vol. 34. N4. Pp. 665-674.

12. Kim Y.H., Won K., Kwon J.M., Jeong H.S., Park S.Y., An E.S., Song B.K. Synthesis of polycardanol from a renewable resource using a fungal peroxidase from Coprinus cinereus // J. Mol. Catal. B. 2005. Vol. 34. N1-6. Pp. 33-38.

13. Chen Q., Xue H., Lin J. Preparation of Polypropylene-graft-Cardanol by Reactive Extrusion and Its Composite Material with Bamboo Powder // J. Appl. Polym. Sci. 2010. Vol. 115, N2. Pp. 1160-1167.

Поступило в редакиию 1 декабря 2011 г.

Glukhikh V.V..$^{*}$, Shkuro A.E. ${ }^{l}$, Shishlov O.F. ${ }^{2}$ SYNTHESIS, PROPERTIES \& APPLICATIONS POLYMERIZATION PRODUCTS OF CARDANOL (REVIEW)

${ }^{1}$ Ural State Forest Engineering University, Sibirskii trakt, 37, Ekaterinburg, 620100 (Russia), e-mail: zj@weburg.m, gvictor@el.ru

${ }^{2}$ Uralchimplast, Severnoye shosse, 21, Nizhny Tagil, Sverdlovsk region, 622012 (Russia), e-mail: o.shishlov@ucp.ru

Synthesis, properties and applications of polymerization and copolymerization products of cardanol which is natural phenol derived from plant materials (Cashew Nut Shell Liquid) were considered. The results of studies of cardanol polymerization in the presence of radical type initiators, cation initiators, enzymes and metal complexes were described. This paper shows that cationic and radical types of catalysts lead to cardanol polymerization by opening the double bonds in alkyl substituent. In case of the oxidative polymerization growth of cardanol polymer chain occurs with the participation of double bonds in the phenolic ring.

Keywords: review, cardanol, polymerization, copolymerization, products, properties, applications.

\footnotetext{
* Corresponding author.
} 


\section{References}

1. Ikeda R., Tanaka H., Uyama H., Kobayashi S. Polymer, 2002, vol. 43, no. 12, pp. 3475-3481.

2. Ikeda R., Tanaka H., Uyama H., Kobayashi S. Polymer J., 2000, vol. 32, no. 7, pp. 589-593.

3. Manjula S., Pillai C.K.S. Polymer News, 1987, vol. 12, no. 12, pp. 359-367.

4. Talbiersky J., Polaczek J., Ramamoorty R., Shishlov O. OIL GAS Europeen Magazine, 2009, no. 1, pp. 33-39.

5. Shishlov O.F., Glukhikh V.V. Khimiia rastitel'nogo syr'ia, 2011, no. 1, pp. 5-16. (in Russ.).

6. Antony R., Pillai C.K.S. J. Appl. Polym. Sci., 1990, vol. 41, no. 7-8, pp. 1765-1775.

7. John G., Pillai C.K.S. Polym. Bull., 1989, vol. 22, no. 1, pp. 89-94.

8. John G., Pillai C.K.S. 33rd IUPAC Int. Symp. Macromol., Montreal, July 8-13, 1990: Book Abstr. Montreal, 1990 , P. 273.

9. Manjula S., Kumar V.G., Pillai C.K.S. J. Appl. Polym. Sci., 1992, vol. 45, no. 2, pp. 309-315.

10. Patent 20030038937 (KR). 2003.

11. Alva K.Sh., Nayak P.L., Kumor J., Tripanthy S.K. J. Macromol. Sci. A, 1997, vol. 34, no. 4, pp. 665-674.

12. Kim Y.H., Won K., Kwon J.M., Jeong H.S., Park S.Y., An E.S., Song B.K. J. Mol. Catal. B, 2005, vol. 34, no. 1-6, pp. 33-38.

13. Chen Q., Xue H., Lin J. J. Appl. Polym. Sci., 2010, vol. 115, no. 2, pp. 1160-1167. 